\title{
Classification of betel leaves (Piper betle) from 15 ethnics in eastern Indonesia based on phytochemicals fingerprint analysis
}

\author{
DIMAS ANDRIANTO ${ }^{1, \boldsymbol{\varphi}}$, HUSNAWATI ${ }^{1}$, SUCI HERMITA ${ }^{1}$, SARI HARYANTI $^{2}$ \\ ${ }^{1}$ Department of Biochemistry, Faculty of Mathematics and Natural Sciences, Institut Pertanian Bogor. Jl. Agatis, IPB University Campus at Dramaga, \\ Bogor 16680, West Java, Indonesia. Tel./fax. +62-251-8423267, •email: dimasandrianto@apps.ipb.ac.id \\ ${ }^{2}$ Medicinal Plant and Traditional Medicine Research and Development Centre, National Institute of Health and Research Development, Indonesian \\ Ministry of Health. Jl. Raya Lawu No 11, Tawangmangu, Karanganyar 57792, Central Java, Indonesia
}

Manuscript received: 8 October 2019. Revision accepted: 25 December 2019

\begin{abstract}
Andrianto D, Husnawati, Hermita S, Haryanti S. 2020. Classification of betel leaves (Piper betle) from 15 ethnics in eastern Indonesia based on phytochemicals fingerprint analysis. Biodiversitas 21: 252-257. Betel (Piper betle Linn), also called Golden Heart of Nature, is often used as traditional medicine. Nonetheless, betel plants originated from different places contains different phytochemicals profile, resulting in different utilization across ethnics. The research aimed to classify betel leaves from eastern Indonesia origins based on phytochemical profiles. In this study, the phytochemical profiles of 69 betel leave samples from 15 ethnics in eastern Indonesia were obtained using High-Performance Liquid Chromatography (HPLC) fingerprint analysis. This data was then used to classify the betel leaves samples using Principal Component Analysis (PCA). The results of the analysis show that the betel leaves from Eastern Indonesia can be divided into three clusters. Cluster 1 consisted of betel leaves originated from two ethnics, namely Komoro and Greri, from Papua, while Cluster 2 consisted of those originated of two ethnics, namely Sumber Baba and Demta, both were also from Papua. Cluster 3 consisted of betel leaves originated 11 ethnics, namely Asilulu (Maluku), Balesang (Central Sulawesi), Bungku (Central Sulawesi), Mulong Kuni (Central Sulawesi), Saluan (Central Sulawesi), Tialo (Central Sulawesi), Tolage (Central Sulawesi), Gebe (North Maluku), Makian (North Maluku), Mey Brat (West Papua) and Waigeo (West Papua). The location of $P$. betle plantation in this research accounts for clusterization of samples, Papua island give the highest biodiversity because we can find all the three cluster in Papua island.
\end{abstract}

Keywords: Piper betel, fingerprints, High-Performance Liquid Chromatography, Principal Component Analysis

\section{INTRODUCTION}

Indonesia has been known as the biodiversity center and utilization of medicinal plants. For example, the ethnic of Mamuju in West Sulawesi Province, Indonesia used about 31 plant species for traditional medicine (Syamsiah et al. 2016). The use of traditional medicine has been increasing due to the negative side effects compared to chemical medicines (Ningsih 2016). However, the lack of documentation of these medicinal plants leads to a lack of knowledge about the potential use of such plant for medicinal purposes.

Betel (Piper betle Linn) leaf is often used as medicinal herb (Sari and Mangunsong 2014). It is very popular in Asia, and often referred to the Golden Heart of Nature (Taukoorah et al. 2016). Traditional people use betel leaves as a mouth freshener, anthelmintic, anti-allergic and antiacne medications (Ririn et al. 2013; Adate et al. 2012; Wirotesangthong et al. 2008; Carolia and Noventi 2016; Sirinivasan et al. 2016). The Batak Toba tribe in North Sumatera, Indonesia used betel leaf to treat eye infection and post-partum treatment (Silalahi et al. 2019). Betel leaf is also used to treat fever by Sanger tribe in Sangihe Islands, North Sulawesi, Indonesia (Pandiangan et al. 2019). The main components of betel leaf that have antimicrobial activity are carvacrol, cavibetol, eugenol, and its isomer (Widjaya et al. 2018). The essential oils from the betel leaf have cytotoxicity and B-glucuronidase inhibition potentials (Karak et al.
2018). The antifertility activity is also reported in betel leaves due to the presence of terpenoids, flavonoids and phytosterols components (Shah and Jhade 2018).

Pratiwi and Muderawan (2016) showed that betel leaves collected from Denpasar, Indonesia contained 31 compounds with its main components consisted of eugenol (25.03\%), 2,5-dimethyl benzoic acid (12.08\%), decahydro$4 \alpha$-methyl-1-methylenyl naphthalene (7.18\%), 1,2,3,4, $4 \alpha, 5,6,8 \alpha$-octahydro-7-methyl naphthalene $(8.36 \%)$ and $1,2,3,4,4 \alpha, 5,6,8 \alpha$-octahydro- $4 \alpha$-methyl naphthalene (13.43\%). According to Pangesti et al. (2017), the main components of betel leaves collected from Semarang, Indonesia included sabinene $(17.23 \%)$, camphene $(12.82 \%), \beta$-cariovilene $(12.70 \%), \beta$-selinene $(10.91 \%)$ and azulene (10.08\%). Another betel leaf collected from Badung, Indonesia contained eucalyptol, cariovilene, $\alpha$ pinene and $\beta$-cubane in its essential oil (Parwata et al. 2009). That research demonstrates that betel leaves originated from different regions could hold different chemical constituents.

Several factors that affect the chemical constituent in plants include genotype, geographical conditions, and agro biophysics interactions. Sukandar and Widayat (2017) proved that plants that come from different locations have different phytochemical compounds. Periyanayagam et al. (2012) carried out profiling research of phytochemical components in betel leaf collected from several regions in India. Previous research by Goyat et al. (2018) showed that 
betel leaves in India can be divided into two main clusters. Purnomo and Asmarayani (2005) reported that Piper betle collected from Yogyakarta was different regarding its essential oil profile.

Fingerprint analysis can be used to reveal data on specific plant phytochemicals compounds (Sukandar and Widayat 2017). The fingerprint results can be further classified using Principle Component Analysis (PCA) method, as the study by Chen et al. (2018) in which the betel leaves were classified based on the profile of phytochemicals using this method. The advantage of PCA is that it produces two dimensional and three-dimensional graph in which the results can be classified globally (Hatik and Gatina 2017), and with using score plot, it can be determined the purity of the data (Wang et al. 2018).

So far, there has been no information about phytochemicals compounds of betel plants collected from eastern region of Indonesia, especially Sulawesi, Maluku, and Papua. In this study, we characterized 69 betel leaf specimens collected from 15 ethnics in eastern Indonesia using High-Performance Liquid Chromatography (HPLC) fingerprint analysis. The research aimed to classify betel leaf from eastern Indonesia origins based on phytochemicals profile. The hypothesis of this research was that the phytochemical profile will be different depending on the area of origin. We expected that this research can provide information about phytochemical compounds in betel leaf and comparison of profiles among betel with various origins from eastern Indonesia.

\section{MATERIALS AND METHODS}

\section{Study area and period}

Samples in this research were 69 samples of betel leaves (Piper betle Linn) collected from 15 ethnic groups living in eastern Indonesia, namely Balesang, Bungku, Mulong Kuni, Saluan, Tialo and Tolage from Central Sulawesi; Gebe, Sumber Baba and Makian from North Maluku; Asilulu and Gebe from Maluku; Mey Brat and Waigeo from West Papua; also Demta, Greri and Komoro from Papua. The samples were collected from July to September 2018.

\section{Materials}

Chemicals used in this research were methanol, water, and acetonitrile. Andrographolide was used as a standard in HPLC analysis.

\section{Procedures \\ Preparation of betel leaf materials}

Samples of betel leaves were picked and dried between 2 pieces of filter papers. The samples were left to dry and delivered to the Medicinal Plant and Traditional Medicine Research and Development Centre in Tawangmangu, East Java by airmail.

\section{Preparation of betel leaf materials into powder}

Dried betel leaf of $150 \mathrm{mg}$ was added into $1.5 \mathrm{~mL}$ microtube contained two metal beads. The tubes were inserted into the Mini-Bead beater and repeatedly ran for 60 seconds until becoming soft powders. The beads were taken out. The tubes were packaged and delivered to the Department of Biochemistry, IPB University by airmail.

\section{Preparation of solution}

One hundred milligrams of betel leaf powder was dissolved in $10 \mathrm{~mL}$ methanol. The solution was ultrasonicated for 15 minutes. The solution was left for 12 hours at room temperature, and it was filtered using a syringe filter. The solution was injected into the HPLC system immediately.

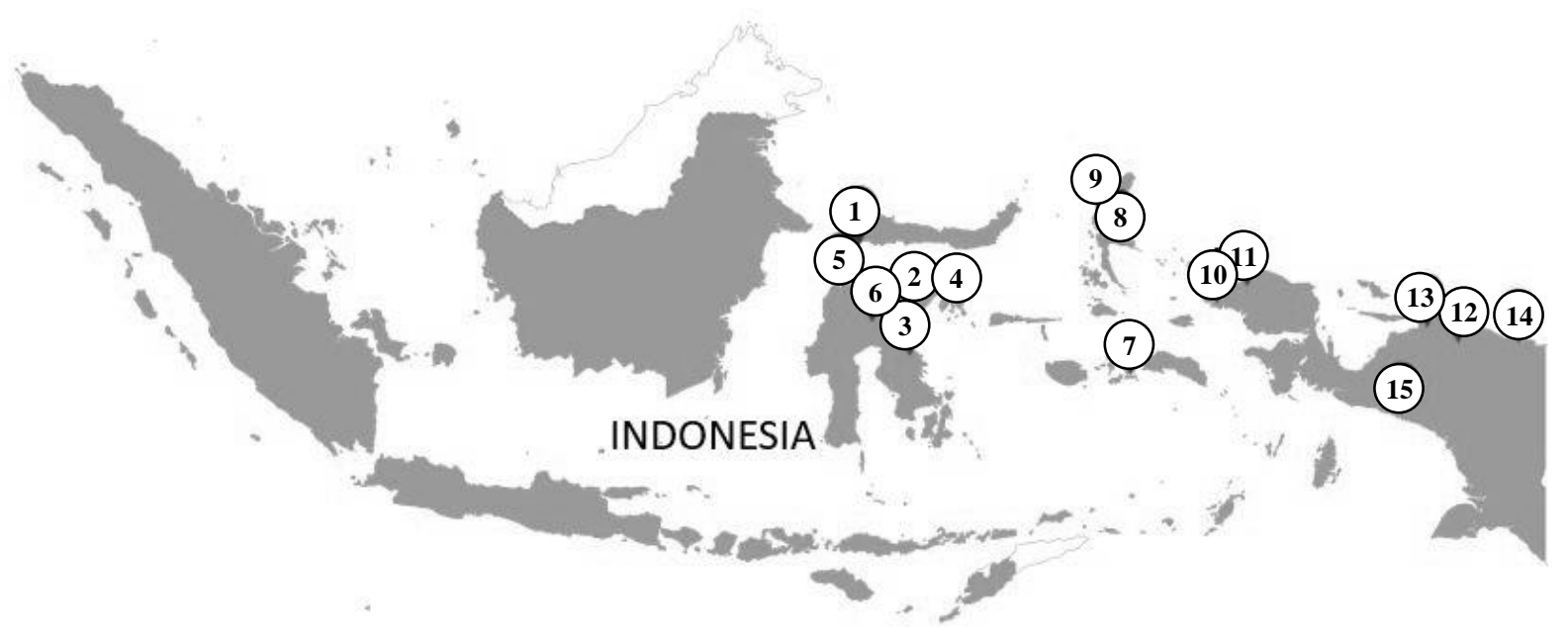

Figure 1. Piper betle Linn leaf samples location in Indonesia. Note: The sites can be seen in Table 1. 
Table 1. Origin of Piper betle Linn leaf samples used in this research

\begin{tabular}{llllll}
\hline No. & Province & Ethnic & District & Topography & Soil type \\
\hline 1 & Central Sulawesi & Balesang & Donggala & Landform vulcano & Ultisol, latosol \\
2 & Central Sulawesi & Bungku & Morowali & Tectonic/structure & Ultisol, podsolic, nitosolic \\
3 & Central Sulawesi & Mulong Kuni & Morowali & Tectonic/structure & Ultisol, podsolic, nitosolic \\
4 & Central Sulawesi & Saluan & Banggai & Landform alluvial & Inceptisol, cambisol \\
5 & Central Sulawesi & Tialo & Donggala & Tectonic/structure & Ultisol, podsolic, nitosolic \\
6 & Central Sulawesi & Tolage & Poso & Tectonic/structure & Inceptisol, kambisol \\
7 & Maluku & Asilulu & Maluku Tengah & Landform vulcano & Ultisol, latosol \\
8 & North Maluku & Gebe & Halmahera Tengah & Tectonic/structure & Oxisol \\
9 & North Maluku & Makian & Maluku Utara & Tectonic/structure & Inseptisol, cambisol \\
10 & West Papua & Mey Brat & Sorong & Lowland, hills slope & Organosol, alluvial, latosol, red- \\
& & & & & yellowish podsolic, and \\
& & & & Tectonic/structure & Ultisol, podsolic, nitosolic \\
11 & West Papua & Waigeo & Sorong & Karst mountains, tectonic, & Dystrodepts, eutrodepts, \\
12 & Papua & Demta & Jayapura & volcanic mountains & hadox, udorthents \\
& & & & Karst mountains, tectonic, & Dystrodepts, eutrodepts, \\
13 & Papua & Sumber Baba & Membramo Raya & volcanic mountains & haplodox, udorthents \\
& & & Basin, tidal & Endoaquent, endoaquept \\
14 & Papua & Greri & Jayapura & Swamp, tidal area & Endoaquent \\
\hline
\end{tabular}

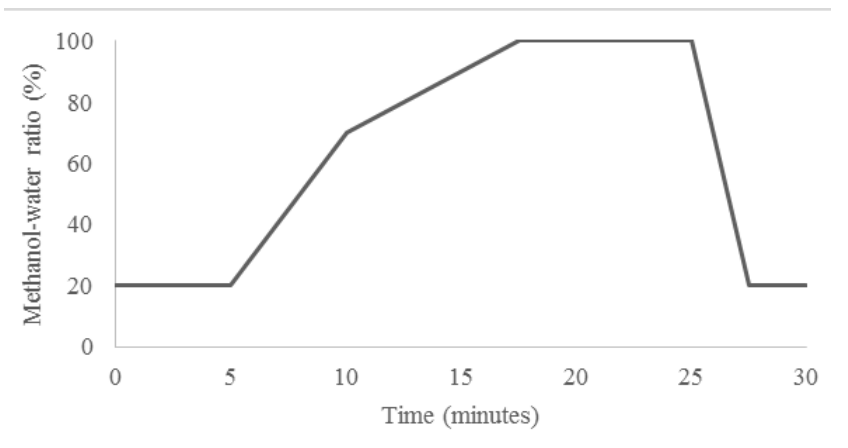

Figure 2. HPLC gradient system of Piper betle methanol extract

\section{HPLC condition for analysis}

We used ODS (RP18) 5.0 um x 150 mm HPLC column and equipped with a Waters C18 column guard. The column temperature was $40^{\circ} \mathrm{C}$. Water and methanol were used as a gradient solvent (Figure 2). The wavelength used in this research was $254 \mathrm{~nm}$. The flow rate was 2 $\mathrm{ml} /$ minute, volume injection was $20 \mu \mathrm{L}$ and operating time was 30 minutes.

\section{Phytochemical profiling of betel leaves by HPLC}

Methanol was injected into the HPLC system as blank. The chromatogram should have baseline no more than three times signal noises. The system was flushed using $100 \%$ water for 15 minutes and $100 \%$ methanol for 15 minutes after the test. Blank was injected after 10 test solution injections completed.

\section{Data analysis}

Classification of betel leaves from various areas in eastern Indonesia was determined based on HPLC fingerprint using Principal Component Analysis (PCA) method. We used Minitab 18 for analyzing the data.

\section{RESULTS AND DISCUSSION}

\section{Classification of betel leaves based on phytochemicals profiles}

Chromatogram data of all samples obtained were analyzed using Principal Component Analysis (PCA) multivariate method. The results of score plot as shown in Figure 3 demonstrate that there are three main clusters of betel leaves collected from eastern Indonesia based on HPLC phytochemicals profiles. The green circle indicates the first group, consisting of betel leaves used by two ethnics, namely Komoro and Greri, from Papua. The second group indicated by the red circle $\mathrm{b}$ consists of betel leaves from two ethnics, namely Mey Brat of West Papua and Demta from Papua. The third group is shown by blue circle $\mathrm{c}$ and consists of betel leaves from 11 ethnics, namely Asilulu (Maluku), Balesang (Central Sulawesi), Bungku (Central Sulawesi), Mulong Kuni (Central Sulawesi), Saluan (Central Sulawesi), Tialo (Central Sulawesi), Tolage (Central Sulawesi), Gebe (North Maluku), Makian (North Maluku), Baba (Papua) and Waigeo (West Papua). The cluster map of the distribution of $P$. betle in eastern Indonesia is presented in Figure 4.

Figure 5 shows the overlay of chromatogram samples from representatives of each group. The chromatogram selected as representative were Komoro for Cluster 1, Demta for Cluster 2, and Bungku for Cluster 3, respectively. All clusters had major peaks in minutes 15 and 13. Cluster 1 still had several peaks between minute 20 and 28 . Cluster 2 had similar pattern with cluster 1 and major peak on minute 23. The Cluster 3 had several peaks between minute 8 and 12 . These results suggest that the betel leaves collected from 15 ethnics in eastern Indonesia have different phytochemicals content, implying that each group had a particular phytochemical compound that became its identifier. 


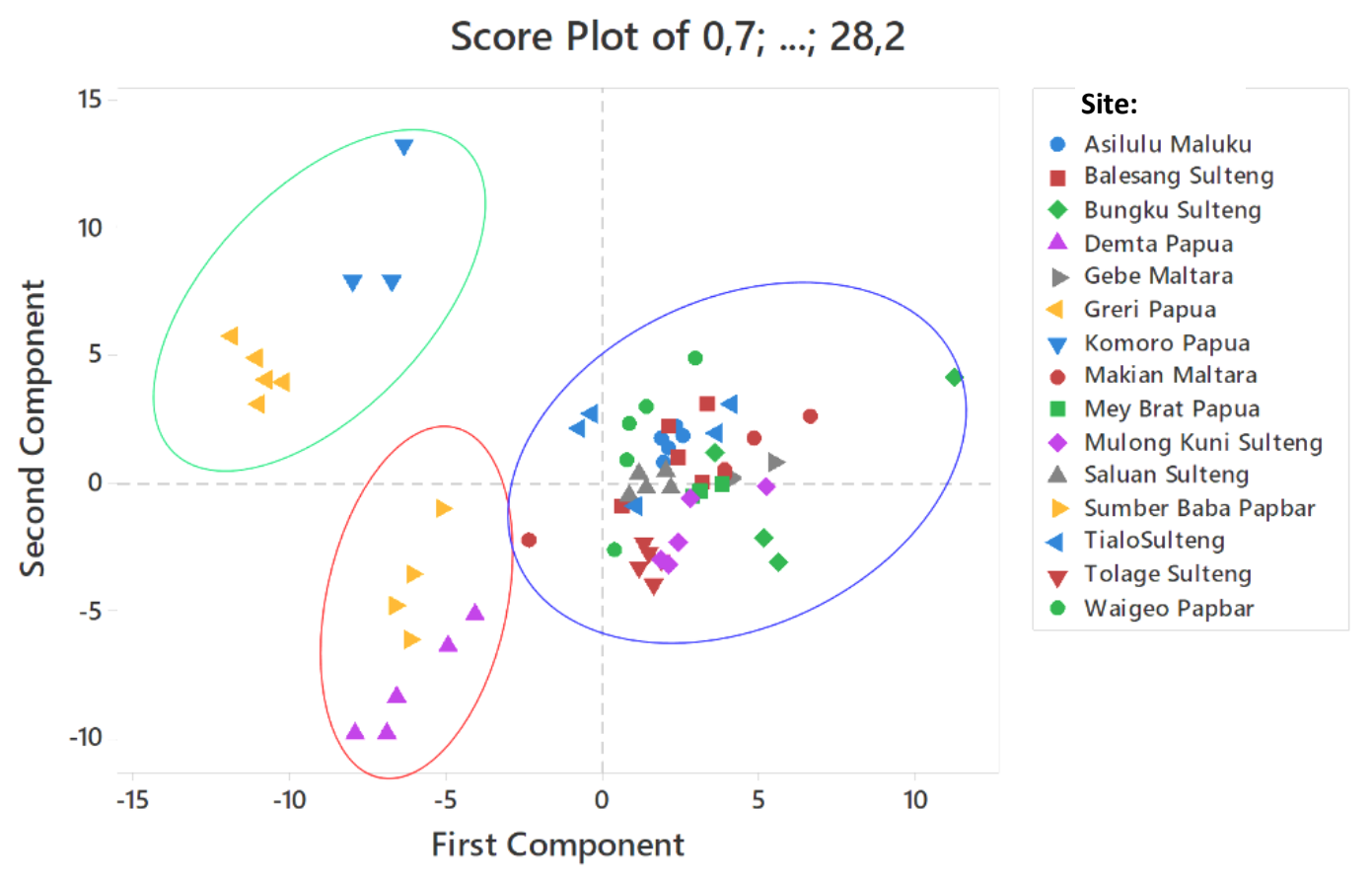

Figure 3. Score plot of betel leaves collected from 15 ethnics in Eastern Indonesia

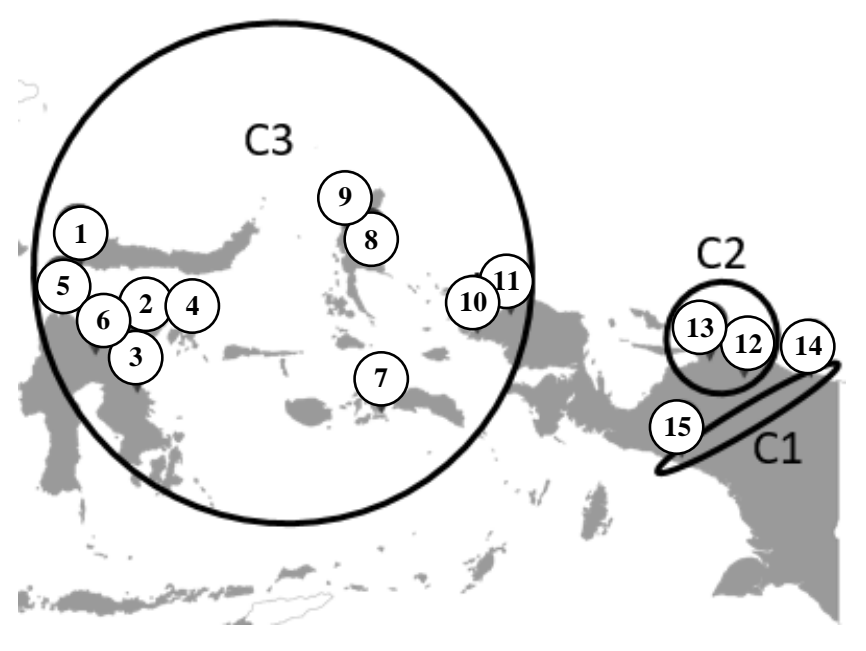

Figure 4. Map of Piper betle cluster in eastern Indonesia: (1) Balesang, Central Sulawesi; (2) Bungku, Central Sulawesi; (3) Mulong Kuni, Central Sulawesi; (4) Saluan, Central Sulawesi; (5) Tialo, Central Sulawesi; (6) Tolage, Central Sulawesi; (7) Asilulu, Maluku; (8) Gebe, North Maluku; (9) Makian, North Maluku; (10) Mey Brat, West Papua; (11) Waigeo, West Papua; (12) Demta, Papua; (13) Sumber Baba, Papua; (14) Greri, Papua; (15) and Komoro, Papua.

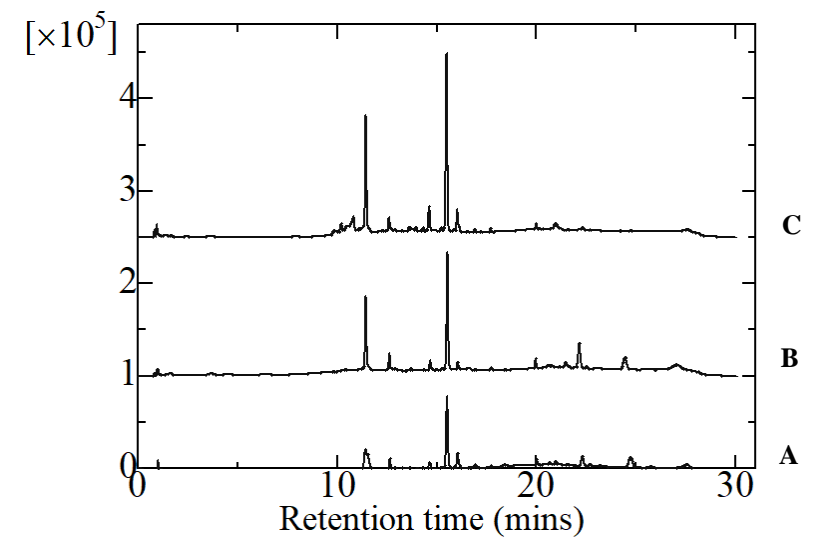

Figure 5. Chromatogram sample of the representative of each group: (A) Komoro, Papua; (B) Bungka, Central Sulawesi; (C) Demta, Papua

\section{Discussion}

In this study, the fingerprint of 69 samples of betel leaves used by 15 ethnics in eastern Indonesia was analyzed using HPLC. Score plot in Figure 3 shows that all of our samples have no outlier. The results showed that betel leaves from eastern Indonesia can be divided into three main clusters based on the score plot. Score plot shows the variation of data analyzed (Ghani et al. 2016). 
These results indicate that betel leaves used by the ethnic of Demta from Papua is not similar to other betel leaves originated from ethnic that also came from Papua, namely Komoros and Greri. Instead, they have similarities with those from Mey Brat from West Papua based on phytochemical profiles. Betel leaves from Papua and West Papua are distributed into three main clusters. Meanwhile, those originated from Maluku, North Maluku and Central Sulawesi turn out to be into one cluster. That fact indicates that all betel leaves originated from ethnics from Maluku, North Maluku and Central Sulawesi region have similarities. These results correspond to studies Suliantari et al. (2018) stating that the active compounds on a betel leaf or source influenced by the origin of betel.

Biogeography condition explains why betel leaves from Sumber Baba and Demta from Papua are in one cluster based on PCA analysis. This result is likely due to the fact that the two ethnics came from the lowland areas. The climatic conditions and the topography of the land in this area have similarities. Sumber Baba is in an area that has a flat topography with altitude 0-250 meters above sea level. The soil types in this area are podsolic brownish-grey, podsolic yellowish red and alluvial. The climate is classified into type A climate with a rainfall average of 2,589 $\mathrm{mm} /$ year. Similarly, Demta area is located at an altitude of 0-500 meters above sea level. The type of soils in the area are alluvial and podsolic. The climate is also classified as type A (Kuswandi et al. 2015).

Betel leaf originated from the ethnics of Greri and Komoro from Papua have the same characteristics. This fact occurs because the two ethnics are located in the same area, namely in the foot of Jayawijaya Mountains. This area is located at an altitude of 30-300 meters above sea level. The type of soils is ultisol, podsolic, brown, grey, yellow and red podzolic alluvial (Kuswandi et al. 2015). However, the characteristics of Greri and Komoro ethnics differ with those from Demta ethnic of Papua as well. The differences are because the Demta ethnic is located on the flat land in the north of the Jayawijaya Mountains. Meanwhile, Greri and Komoro ethnics are located along the north and south coast of Papua Island. Miswarti et al. (2014) stated that geographical proximity is one of the factors that cause the plant to have a resemblance to secondary metabolites.

The areas of Makian and Gebe ethnics from North Maluku have a dry climate with an average rainfall of $1,715 \mathrm{~mm} /$ year. Soil condition in the area is affected by the Halmahera Mountain. The soil in this area is volcanic soil that has high organic content (Suryani et al. 2015). The areas of Balesang and Tolage ethnics (Central Sulawesi) are close to the valley of the Halmahera Mountain which has a dry climate (Hikmatullah and Sukarman 2007).

Suryani and Ritung (2018) stated that the areas of Central Sulawesi in which Saluan, Tialo, Mulong Kuni and Bungku ethnics are located on hills and mountains. Betel leaf used by Mey Brat ethnic which belongs to Cluster 3 was originated from mountain regions. All the betel samples of this cluster are under one cluster because they had the same geographic conditions, which is mountainous regions. This is in line with the research by Nurcholis et al.
(2016) which found that the condition of agro-biophysics largely affects the growth and diversity of the secondary metabolite profiles.

In conclusion, betel leaves from eastern Indonesia can be divided into three main clusters based on the results of the analysis of the PCA. The first cluster consisted of two ethnics, namely Komoro and Greri, from Papua. The second cluster was composed of two ethnics, namely Sumber Baba and Demta which also from Papua. The third cluster consisted of 11 ethnics, namely Asilulu (Maluku), Balesang (Central Sulawesi), Bungku (Central Sulawesi), Mulong Kuni (Central Sulawesi), Saluan (Central Sulawesi), Tialo (Central Sulawesi), Tolage (Central Sulawesi), Gebe (North Maluku), Makian (North Maluku), Mey Brat (West Papua) and Waigeo (West Papua).

\section{ACKNOWLEDGEMENTS}

Acknowledgements are expressed to Medicinal Plant and Traditional Medicine Research and Development Centre, National Institute of Health and Research Development, Ministry of Health that has funded this research through RISTOJA 2018 Program.

\section{REFERENCES}

Adate PS, Parmesawaran S, Chauhan Y. 2012. In vitro anthelmintic activity of stem extracts of Piper betle Linn against Pheritima posthuma. Phcog J 29 (4): 61-65.

Carolia N, Noventi W. 2016. The potential of green sirih leaf (Piper betle L.) for alternative therapy Acne vulgaris. Majority 5 (1):140-145

Chen YS, Aluwi NA, Saunders SR, Ganjyal GM, Meza IGM. 2018. Metabolic fingerprinting unveils quinoa oil as a source of bioactive phytochemicals. Food Chem 286: 592-599.

Ghani ZDFA, Husin JM, Rashid AHA, Shaari K, Chik Z. 2016. Biochemical studies of Piper betle $\mathrm{L}$ extract on the obese treated animal using the 1H-NMR-based metabolomics approach of blood serum samples. J. Ethnopharmacol 194: 690-697.

Goyat S, Grewal A, Bindu KH, Singh D, Katiyar RS, Tewari SK, Nainwal R. 2017. Amplified fragment length polymorphism (AFLP) based genetic diversity studies in betel vine (Piper betle L.). East African Agric For J 82 (2): 118-129.

Hatik C, Gatina JC. 2017. Wate production classification and analysis: a PCA-induced methodology. Energy Procedia 136 (4): 488-494.

Hikmatullah, Sukarman. 2007. Evaluation of soil properties of the alluvial landform in three locations of Donggala District, Central Sulawesi. Jurnal Tanah dan Iklim. 25 (3): 69-82. [Indonesian]

Karak S, Acharya J, Begum S, Mazumdar I, Kundu R, De B. 2018. The essential oil of Piper betle L. leaves chemical composition, anti-acety; cholinesterase, anti- $\beta$-glucuronidase and cytotoxic properties. J Appl Res Med Aromat Plants 10 (3): 85-92.

Kuswandi R, Sadono R, Supriyanto N, Marsono D. 2015. Diversity of stand structure in logged-over forest based on Papua biogeography. Jurnal Manusia dan Lingkungan 22 (2): 151-159. [Indonesia]

Miswarti, Nurmala T, Anas. 2014. Characterization and relationship 42 accessions of foxtail millet plant (Setaria italica L. Beauv). Pangan 23 (2): 166-177.

Ningsih IY. 2016. Ethnopharmacy study of medicinal plants used by Tengger tribe in Lumajang dan Malang, Jawa Timur. Pharmacy: Jurnal Farmasi Indonesia 13 (1): 10-20. [Indonesia]

Nurcholis W, Khumaida N, Syukur M, Bintang M. 2016. Similarity analysis of 20 promising accessions of Curcuma aeruginosa Roxb. Based on rhizome color, extract yield and phytochemical content. J Agron Indonesia 44 (3): 315-321. 
Pandiangan D, Silalahi M, Dapas F, Kandou F, 2019. Diversity of medicinal plants and their uses by the Sanger tribe of Sangihe Islands, North Sulawesi, Indonesia. Biodiversitas 20 (2): 621-631.

Pangesti RD, Cahyono E, Kusumo E. 2017. Comparison of the antibacterial activity of extract and oil of Piper betle L. against Streptococcus mutans bacteria. Indones. J Chem 6 (3): 270-278.

Parwata IMOA, Rita WS, Yoga R. 2009. The isolation and test of free antiradical essential oil in the betel leaf (Piper betle Linn) using ultraviolet-visible spectroscopy. J Chem 3 (1): 7-13.

Periyanayagam K, Jagadeesan M, Kavimani S, Vetriselvan T. 2012. Pharmacognostical and phyto-physicochemical profile of the leaves of Piper betle L. var Pachaikodi (Piperaceae)-valuable assessment of its quality. Asian Pac J Trop Biomed 2 (2): S506-S510.

Pratiwi NPRK, Muderawan IW. 2016. Analysis of the chemical content of green betel leaf extract (Piper betle) with GC-MS. Proceeding of Nasional Seminary, Universitas Pendidikan Unesha, Singaraja. [Indonesian]

Purnomo, Asmarayani R. 2005. Relationship of species Piper based on morphological and leaf essential oils characters in Yogyakarta. Biodiversitas 6 (1): 12-16. [Indonesian]

Ririn, Tandjung AI, Wagola S. 2013. Formulation of mouthwash from extract betel lead (Piper betle L.) siriboah variety. As-Syifaa Jurnal Farmasi 5 (2): 153-161. [Indonesian]

Sari A, Mangunsong S. 2014. Effect of betel leaf extract (Piper betle L) to decrease serum uric acid and urea levels in rat. Mutiara Medika: Jurnal Kedokteran dan Kesehatan.14 (1): 93-99. [Indonesian]

Shah SK, Jhade DN. 2018. Evaluation of the antifertility potential of Piper betle (petiole) on female Wistar rats "rising approaches of herbal contraception". B B Reports 15 (4): 97-102.

Silalahi M, Nisyawati, Pandiangan D. 2019. Medicinal plants used by Batak Toba Tribe in Peadundung Village, North Sumatra, Indonesia. Biodiversitas 20 (2): 510-525.

Srinivasan R, Devi KR, Kannappan A, Pandian SK, Ravi AV. 2016. Piper betle and its bioactive metabolite phytol mitigate quorum sensing mediated virulence factors and biofilm of nosocomial pathogen Serratia marcescens in vitro. J Ethnopharmacol 17: 1-33.

Sukandar PB, Widayat T. 2017. Exploring the local knowledge of Etnomedisin and community-based medicinal plants in Indonesia by the Great Hall of Research and development of traditional medicinal and medicinal plants. Ministry of Health Indonesia, Jakarta. [Indonesian]

Suliantari, Jenie BSL, Suhartono MT, Apriyantono A. 2008. Antibacterial activity of green sirih (Piper betle L) extract towards food pathogens. J Teknologi dan Industri Pangan 19 (1): 1-7. [Indonesian]

Suryani E, Hikmatullah, Suratman. 2015. Mineralogical and physicochemical characteristics of volcanic ash soils in Halmahera, North Maluku, Indonesia. Jurnal Tanah dan Iklim 39 (2): 85-98. [Indonesian]

Suryani E, Ritung S. 2018. Soils derived from ultrabasic rock in Sulawesi: Heavy metal content and proposed soil management for agriculture. Jurnal Tanah dan Iklim 42 (2): 111-124. [Indonesian]

Syamsiah S, Hiola SF, Mu'nisa A, Jumadi O. 2016. Study on medicinal plants used by the ethnic Mamuju in West Sulawesi, Indonesia. J Tropical Crops 3 (2): 42-48.

Taukoorah U, Lall N, Mahomoodally F. 2016. Piper betle L. shows bacteriostatic, additive and synergistic antimicrobial action when combined with conventional antibiotics. South Africa J Bot 105 (3): 133-140.

Wang YF, Yu, J, Su GP, Qian YR. 2018. New outlier detection method based on OPTICS. Sustain. Cities Soc 45: 197-212.

Widjaya FE, Retnani Y, Hermana W. 2018. Effect of Piper betle L. supplementation on egg quality of quails. J Ilmu Pertanian Indonesia 23 (1): 1-9.

Wirotesangthong M, Inagaki N, Tanaka H, Thanakijcharoenpath W, Nagai H. 2008. Inhibitory effects of Piper betle on the production of allergic mediators by bone marrow-derived mast cells and lung epithelial cells. Intl Immunopharmacol 8: 453-457. 